\title{
ANALISIS KEPATUHAN IBU TERHADAP IMUNISASI DI MASA PANDEMIC COVID 19 DI KLINIK CAHAYA BUNDA
}

\author{
Kursiah Warti Ningsih ${ }^{1)}$, Dona Martilova ${ }^{2)}$, Ambiyar ${ }^{3)}$, Fadhilah $^{4)}$ \\ Universitas Negeri Padang ${ }^{1,3,4}$ \\ STIKes Payung Negeri Pekanbaru ${ }^{2}$ \\ E-mail : kursiahwarti@gmail.co.id ${ }^{1)}$,dhonalova@gmail.com ${ }^{2}$
}

\section{Kata Kunci: \\ Imunisasi, covid 19, kecemasan}

\section{Keywords:}

Immunization, covid 19, anxiety

\section{Info Artikel}

Tanggal dikirim: 23-12-2020

Tanggal direvisi: 20-3-2021

Tanggal diterima: 09-06-2021 DOI Artikel:

10.36341/jomis.v5i2.1590

Creative Commons Attribution-

NonCommercial-ShareAlike 4.0 International License.

\begin{abstract}
ABSTRAK
Tubuh manusia rentan untuk mengalami sakit, salah satu cara dalam meningkatkan kekebalan tubuh adalah dengan memberikan imunisasi. Dengan imunisasi dampak suatu penyakit dapat lebih ringan karena sebelumnya telah diberikan kekebalan. Di sekitar kita banyak bayi maupun balita belum diberikan imunisasi, hal ini disebabkan oleh beberapa hal seperti pemahaman orang tua tidak mendukung imunisasi, akhirnya banyak bayi maupun balita yang tidak diberikan pelayanan program imunisasi. Beberapa diantara alasannya yang disampaikan oleh orangtua maupun keluarga mengenai pemahaman yang berbeda mengenai imunisasi, antara lain karena adanya efek samping anak menjadi panas setelah imunisasi, sering sakit, keluarganya tidak mengizinkan, tempat pelaksanaan imunisasi jauh, tempat imunisasi sulit di termukan, serta kesibukan, di tambah lagi dengan kondisi saat ini dengan adanya wabah covid 19. Penelitian bertujuan untuk mengetahui bagaimanakah kepatuhan ibu terhadap imunisasi pada masa pandemic covid 19 di Klinik Cahaya Bunda Pekanbaru. Seluruh bayi usia 0-12 bulan sebanyak 128 bayi sebagai sampel dengan teknik total sampling. Analisa bivariat menggunakan chisquare, dan di tetapkan $p$ value $=0,05$. Berdasarkan hasil penelitian ini ditemukan bahwa terdapat hubungan antara variable usia ibu, pendidikan, pekerjaan, kecemasan ibu, dan pendapatan keluarga terhadap kepatuhan ibu terhadap imunisasi pada masa pandemic covid 19 ( $p$ value $<0,05$ ). Diharapkan kepada tenaga kesehatan untuk lebih memberikan edukasi tentang pentingnya melakukan imunisasi di masa pandemic dengan menerapkan prosedur kesehatan pencegahan covid 19.
\end{abstract}

\begin{abstract}
The human body is susceptible to illness, one way to increase immunity is by providing immunizations. With immunization, the impact of a disease can be lighter because it has previously been given immunity. Around us there are still many babies and toddlers who have not received immunization, this is due to several things such as parents' understanding that they do not support immunization, so that many babies and toddlers are not provided with immunization program services. Some of the reasons given by parents and families regarding different understandings about immunization, among others, are due to the side effects of children getting hot after immunization, frequent illness, their families do not allow them, the place for immunization is far, where immunization is difficult to find, and busy, in added to the current conditions with the covid 19 outbreak. The study aims to determine how the mother's compliance with immunization during the Covid 19 pandemic at the Cahaya Bunda Clinic in Pekanbaru. All babies aged 0-12 months were 128 babies as a sample with a total sampling technique. Bivariate analysis using chi-square, and set $p$ value $=0.05$. Based on the results of this study, it was found that there was a relationship between the variables of maternal age, education, occupation, maternal anxiety, and family income on maternal compliance with immunization during the COVID-19 pandemic ( $p$ value $<0.05$ ). It is hoped that health workers will provide more education about the importance of immunizing during the pandemic by implementing health procedures to prevent covid 19.
\end{abstract}

\section{PENDAHULUAN}

Tubuh manusia rentan untuk mengalami sakit, salah satu cara dalam meningkatkan kekebalan tubuh adalah dengan memberikan imunisasi. Dengan imunisasi dampak suatu penyakit dapat lebih ringan karena sebelumnya telah diberikan kekebalan. Di sekitar kita di masih ditemukan bayi maupun balita belum diberikan imunisasi, hal ini disebabkan oleh beberapa hal: pemahaman tentang imunisasi yang berbeda, jadi akhinya bayi maupun balita tidak diberikan pelayanan imunisasi. Beberapa diantara alasannya oleh orangtua adalah pemahaman yang berbeda mengenai imunisasi, antara lain karena adanya efek samping anak menjadi panas setelah 
imunisasi, sering sakitnya bayi maupun balita setelah imunisasi, keluarganya tidak mengizinkan, jauhnya tempat imunisasi dari rumah, tempat imunisasi yang sulit di temukan, serta kesibukan, di tambah lagi dengan kondisi saat ini dengan adanya wabah covid 19[1]. Dengan timbulnya COVID-19 secara global sejak ditetapkannya sebagai Public Health Emergency of International Concern (PHEIC) pada tanggal 30 Januari 2020 dan ditetapkan sebagai pandemi pada tanggal 11 Maret 2020 oleh WHO, memberikan dampaknya pada pelaksanaan program kesehatan khususnya pelayanan imunisasi dan surveilans PD3I. Hasil kajiannya menunjukkan bahwa $84 \%$ Puskesmas menyatakan bahwa selama masa pandemi COVID-19 terjadi penundaan/penghentian pelayanan Imunisasi. Hal ini diakibatkan oleh timbulnya kekhawatiran orang tua maupun keraguan pada petugas kesehatan dalam menyelenggarakan layanan imunisasi ditengah pandemi COVID-19. [2]

Imunisasi adalah salah satu cara yang cukup efektif untuk mencegah beberapa penyakit menular dan sangat berperan penting dalam penanggulangan masalah kesehatan. Sehingga, di harapkan nantinya anak tidak mudah untuk tertular infeksi dan anak tidak mudah mengalami sakit setelah diberikan imunisasi, serta dapat dilakukan pencegahan pada wabah penyakit dan dapat pula mencegah kemungkinan terjadinya kematian yang disebbakan oleh suatu penyakit. Perlunya imunisasi ini pada hakikatnya merupakan pemikiran paradigma sehat yang berfokus pada kegiatan promotif dan kegiatan preventif yang merupakan hal yang sangat penting dalam meningkatkan status kesehatan. [3]

Berdasarkan data WHO, 1,5 juta anak meninggal setiap tahunnya yang disebabkan oleh penyakit yang harusnya dapat di cegah dengan diberikan imunisasi. Tahun 2018, 20 juta anak tidak memperoleh imunisasi lengkap dan masih cukup banyak anak yang tidak mendapatkan imunisasi satu kalipun. [4]

Untuk pencapaian cakupan imunisasi dasar lengkap, Provinsi Riau belum mencapai target. Ketercapaian imunisasi hanya $73 \%$ sementara target imunisasi adalah 93\%. Berdasarkan data Imunisasi Dasar Lengkap (IDL) juga masih belum memenuhi target dengan yang ditetapkan (92,5\%) dan IDL yang di capai hanya $73 \%$. Propinsi Riau hanya ada 2 Kabupaten/ Kota yang mencapai target IDL yaitu Kota Dumai 96,8\%, dan Kabupaten Kepulauan Meranti 92,8\%. Kabupaten/ Kota yang tidak mencapai target ada $10 \mathrm{Kab} / \mathrm{Kota}$ dengan cakupan terendah Kabupaten Inhil 40,6\%, Inhu 42,1\%, Kuansing 58,9\%, Bengkalis 61\%, Kampar 66,8\%, Pekanbaru $68,7 \%$, Siak 68,9\%, Rohil 72,3\%, Rohul $84,4 \%$, dan Pelalawan 91,3\%. UCI desa di Provinsi Riau tahun 2018 sebesar 63,7 \%, sedikit meningkat jika dibandingkan dengan tahun $2017(62,6 \%)$ tetapi masih jauh dibawah target (90\%), atau capaian kinerja 70 $\%$. Capaian kinerja sebesar $70 \%$ dinilai cukup berhasil, perlu mendapat perhatian untuk ditingkatkan kinerjanya. Jumlah desa di Provinsi Riau tahun 2018 terdiri dari 1.873 desa, dan desa yang dapat mencapai UCI hanya 1.193 desa $(63,7 \%)$ [5]. Sedangkan UCI di kota pekanbaru tahun 2019 ini yaitu 86,7\% dan belum mencapai target nasional yaitu 90\%. [6]

Dari data yang dilihat masih belum tercapainya program imunisasi secara lengkap. Banyak sekali faktor yang mempengaruhinya Masih banyak pemahaman masyarakat masih yang berbeda terhadap imunisasi, akibatnya masih banyak bayi mapun balita yang tidak mendapatkan atau orang tua tidak mau mengikuti pelayanan imunisasi. Ada banyak alasan yang disampaikan orangtua tentang pemahaman yang berbeda mengenai imunisasi, antara lain karena akibat efek samping setelah dilakukan imunisasi, diantaranya anak menjadi panas/ demam, anak menjadi sering sakit, keluarga yang tidak mengizinkan, jauhnya imunisasi, tidak tahu tempat imunisasi, maupun kesibukan orang tua. Akibat beberapa alasan tersebut akibatnya pelayanan imunisasi harus ditingkatkan pada berbagai tingkat pelayanan [7] [8]. Hasil penelitian terkait mengatakan beberapa faktor yang dapat membuat rendahnya cakupan imunisasi antara lain yaitu faktor sikap petugas/ tenaga kesehatan, tempat pelaksanaan 
imunisasi, kehadiran/ sikap petugas, usia ibu, status pendidikan ibu, status pendapatan keluarga, ketakutan terhadap dampak imunisasi, pekerjaan ibu, kebiasaan/ tradisi keluarga, pengetahuan ibu, dan dukungan keluarga.

Ditambah dengan kondisi sekarang dimasa penularan virus Corona [9]. Pandemi covid 19 berimbas secara langsung pada banyak hal. Jadwal kegiatan imunisasipun tidak luput dari dampak covid 19 ini. Banyak orang tua yang ragu dna khawatir untuk membawa anaknya ke rumah sakit atau puskesmas untuk melakukan imunisasi karena takut tertular virus yang sudah menginfeksi jutaan orang di seluruh dunia ini. [10]. Berdasarkan hasil survei awal peneliti di Klinik Cahaya Bunda, bahwa 70\% ibu yang memiliki anak bayi mapun balita tidak melakukan imunisasi dalam 3 bulan terakhir sejak mewabahnya pandemic covid 19. Berdasarkan hasil wawancara dengan beberapa orang ibu yang memiliki bayi mapun balita sebagian besar mengatakan takut untuk melakukan imunisasi ke tenaga kesehatan dikarenakan virus yang sedang menyebar saat ini. Untuk itulah penulis ingin melakukan penelitian terkait analisis kepatuhan orang tua dalam melakukan imunisasi dimasa pandemi covid 19 di klinik Cahaya Bunda Pekanbaru.

Tujuan penelitian ini adalah untuk mengetahui apa saja factor yang dapat mempengaruhi ibu dalam melakukan imunisasi pada saat wabah covid 19 di Klinik Cahaya Bunda Pekanabru. Diharapkan dengan adanya peelitian ini dapat memberikan manfaat bagi klinik dan ibu tentang bagaimana penatalaksnaan imunisasi yang aman bagi ibu dan tenaga kesehatan di klinik, sehingga imunisasi tetap dapat dilakukan secara optimal.

\section{TINJAUAN PUSTAKA \\ Imunisasi}

Vaksin yaitu antigen berupa mikroorganisme yang sudah di lemahkan, masih hidup, masih utuh atau bagiannya diolah menjadi toksin mikroorganisme yang telah yang dapat menjadi toksoid, dimana protein rekombinan yang bila diberikan pada seseorang akan menimbulkan kekebalan yang spesifik pada individu yang diberikan dan secara aktif pada penyakit infeksi tertentu. [11]

Dengan imunisasi diharapkan anak menjadi kebal terhadap suatu penyakit. Sehingga jika anak terjangkit penyakit tersebut kondisi tingkat keparahan penyakit tersebut sudah tidak membahayan anak tersebut. Pemberian imunisasi pada anak bertujuan untuk membuat tubuh anak menjadi kebal terhadap penyakit tertentu, kekebalan tubuh tersebut juga dapat di pengaruhi oleh beberapa faktor yang diantaranya adalah tingginya kadar antibody pada saat dilakukan imunisasi, maupun potensi antigen yang disuntikan, dan waktu antara pemberian imunisasi. [12]

Jenis jenis imunisasi:

a. MMR

Dengan pemberian Imunisasi berguna untuk pemberian kekebalan terhadap beberapa penyakit yaitu penyakit campak (measles), gondong dan parotis epidemika (mumps), serta campak Jerman (rubella).

b. Hib

Pemberian imuniasi ini (tipe b) berguna dalam mencegah anak dari penyakit influenza tipe $b$.

c. Varicella

Dengan Imnisasi ini anak dapat terhindar dari penyakit cacar air.

d. Hepatitis A

Dengan diberikannya anak imunisasi ini maka penyakit hepatitis A dapat dihindari.

e. Pneumokokus

Vaksin ini ditujukan dalam mengurangi mortalitas akibat dari pneumokokus invasive, yaitu pneumonia, bakteriemia, dan meningitis.

f. Influenza

Vaksin ini mengandung virus yang sudah tidak aktif (inactivated influenza virus). Ada dua macam jenis vaksin, yaitu wholevirus vaccine dan split virus vaccine.

g. Tifoid

Vaksin ini mempunyai dua jenis yaitu vaksin demam tifoid, dengan vaksin suntikan dan vaksin tifoid oral. Seseorang dianjurkan untuk imunisasi tifoid sebelum 
ataupun setelah berpergian ke daerah dengan resiko tinggi terjadinya demam tifoid.

\section{METODE}

Penelitian ini merupakan penelitian analitik kuantittatif dengan pendekatan studi cross sectional. Populasi penelitian ini adalah semua bayi $0-12$ bulan yang berkunjung di Klinik Cahaya Bunda pada bulan Januari - April tahun 2020 sebanyak 128 bayi yang keseluruhannya di jadikan sampel (Total Sampling). Pengumpulan data dilakukan door to door ke rumah bayi yang berkunjung di Klinik Cahaya Bunda yang di lakukan selama 3 bulan (Mei sd Juli 2020) dengan melakukan wawancara kepada ibu/ keluarga bayi. Pengolahan Data menggunakan uji statistik chi square dengan $p$ value $=0,05$.

\section{HASIL DAN PEMBAHASAN}

Setelah dilakukan analisa silang dapat dilihat pada Tabel 1.

Tabel 1 Umur dengan Kepatuhan Ibu

\begin{tabular}{|c|c|c|c|c|c|c|c|c|}
\hline \multirow[t]{2}{*}{ Variabel } & \multicolumn{4}{|c|}{ Kepatuhan Ibu } & \multirow[t]{2}{*}{$\mathbf{n}$} & \multirow[t]{2}{*}{$\%$} & \multirow{2}{*}{$\begin{array}{c}P \\
\text { value }\end{array}$} & \multirow[t]{2}{*}{ POR $_{(95 \%)} \mathrm{CI}$} \\
\hline & $\begin{array}{c}\text { Tidak Patuh } \\
\mathbf{n}\end{array}$ & $(\%)$ & $\begin{array}{c}\text { Patuh } \\
\text { n }\end{array}$ & $(\%)$ & & & & \\
\hline \multicolumn{9}{|l|}{ Umur } \\
\hline$<35$ tahun & 55 & 86,4 & 10 & 15,4 & 65 & 100 & \multirow[t]{3}{*}{0,019} & 2.951 \\
\hline$>=35$ tahun & 41 & 65,1 & 22 & 34,9 & 63 & 100 & & $(1.262-$ \\
\hline Total & 96 & 75 & 32 & 25 & 128 & 100 & & $6.904)$ \\
\hline \multicolumn{9}{|l|}{ Pendidikan } \\
\hline Rendah & 58 & 86,6 & 9 & 13,4 & 67 & 100 & \multirow[t]{3}{*}{0,003} & 3.901 \\
\hline TInggi & 38 & 62,3 & 23 & 37,7 & 61 & 100 & & (1.630- \\
\hline Total & 96 & 75 & 32 & 25 & 128 & 100 & & 9.333) \\
\hline \multicolumn{9}{|l|}{ Pekerjaan } \\
\hline Tidak Bekerja & 47 & 88,7 & 6 & 11,3 & 53 & 100 & \multirow[t]{3}{*}{0,005} & 4.156 \\
\hline Bekerja & 49 & 65,3 & 36 & 34,7 & 75 & 100 & & $(1.570-$ \\
\hline Total & 96 & 75 & 32 & 25 & 128 & 100 & & 11.005) \\
\hline \multicolumn{9}{|l|}{ Kecemasan ibu } \\
\hline Cemas & 72 & 85,7 & 12 & 14,3 & 84 & 100 & \multirow[t]{3}{*}{0,0001} & 5.000 \\
\hline Kurang Cemas & 24 & 54,5 & 20 & 45,5 & 44 & 100 & & $(2.133-$ \\
\hline Total & 96 & 75 & 32 & 25 & 128 & 100 & & 11.720) \\
\hline \multicolumn{9}{|c|}{ Pendapatan keluarga } \\
\hline$<3.000 .000$ & 46 & 88.5 & 6 & 11.5 & 52 & 100 & \multirow[t]{3}{*}{0,007} & 3.987 \\
\hline$\geq 3.000 .000$ & 50 & 65.8 & 26 & 34.2 & 76 & 100 & & (1.506- \\
\hline Total & 96 & 75 & 32 & 25 & 128 & 100 & & 10.557) \\
\hline
\end{tabular}

\section{Umur dengan Kepatuhan Ibu}

Dari uji Chi Square didapat $p_{\text {value }}=$ $0,019 \quad(<0,05)$ sehingga hal ini berarti ada hubungan antara Umur dengan Kepatuhan Ibu dengan $(\mathrm{POR})=2.951(1.262-6.904)$ yang artinya responden dengan umur $<35$ tahun, 2,9 kali berisiko kurang kurang patuh dibandingkan dengan responden dengan umur $>=35$ tahun .

Dari 100 orang responden di dapatkan responden mayoritas berusia: kelompok dewasa (25 - 45 tahun) sebanyak 72 orang $(72 \%)$. Pada usia tersebut termasuk usia dewasa, dimana masa tersebut seseorang telah dianggap matur/ dewasa, baik dilihat secara fisiologis, psikologis, serta kognitif. Pada usia dewasa kebiasaan berpikir rasional menjadi lebih meningkat. Peningkatan umur ibu dapat menambah pengalaman ibu dalam mengurus dan mengasuh anak, dengan demikian peningkatan umur menentukan pengalaman ibu, sehingga ibu lebih matang dan lebih 
berpengalaman dalam melakukan upaya proventif bagi anaknya termasuk melakukan imunisasi untuk anaknya. Karena itu umur merupakan factor yang cukup perlu diperhitungkan dalam pencapaian imunisasi anaknya. [13]

\section{Tingkat Pendidikan dengan Kepatuhan Ibu}

Hasil uji Chi Square didapat $p_{\text {value }}=$ $0,003(<0,05)$ hal ini yang berarti ada hubungan antara tingkat pendidikan dengan kepatuhan ibu dengan $\mathrm{POR}=3.901$ (1.6309.333) yang artinya responden dengan tingkat pendidikan rendah, 3,9 kali berisiko kurang kurang patuh dibandingkan dengan responden dengan tingkat pendidikan tinggi.

Berdasarkan teori tentang pendidikan mengatakan bahwa semakin tinggi tingkat pendidikan seseorang maka dapat membuat semakin tinggi pula pemahaman seseorang tersbut, sehingga dapat dikatakan tingkat pendidikan juga sangat berperan dalam penyerapan dan pemahaman terhadap informasi. Pendidikan pada dasarnya memiliki peranan yang sangat penting dalam menentukan kualitas manusia, dengan adanya pendidikan, manusia juga akan memperoleh pengetahuan dan informasi. Semakin tinggi tingkat pendidikan seseorang maka akan semakin berkualitas pula hidupnya. Dengan demikian semakin tingginya pendidikan seseorang maka semakin besar kesadaran dalam pelaksaan pemeberian imunisasi kepada anak dan ibu dapat menerima informasi yang diberikan serta dapat mengambil keputusan yang lebih dewasa untuk kesehatan bayi maupun balitanya terutama dalam melaksanakan imunisasi. [14] [15]

Penelitian ini juga sesuai dengan penelitian yang menunjukkan hasil ujian ststistik dengan menggunakan metode fisher exact test, maka diperoleh nilai $\rho=0,025$. Dengan demikian nilai $\rho<\alpha(0,05)$, Dimana pendidikan ibu berkaitan terhadap program pemberian imunsasi yang akan dilaksanakan pada bayi. Pendidikan dari seseorang termasuk salah satu proses dalam menentukan tempattempat pelayanan kesehatan dan semakin diperhitungkan. Pendidikan secara langsung akan mempengaruhi pola pikir seseorang ibu sehingga akan menentukan apa orang tua dalam hal ini ibu akan memberikan imunisasi pada bayinya sehingga pendidikan mempengaruhi status imunisasi dasar bayi. [16]

\section{Pekerjaan dengan Kepatuhan Ibu}

Hasil penelitian didapat $p_{\text {value }}=0,005$ $(<0,05)$ hal ini berarti ada hubungan antara pekerjaan dengan kepatuhan ibu dengan POR $=4.156(1.570-11.005)$ yang artinya responden tidak bekerja, 4,1 kali berisiko kurang patuh dibandingkan dengan responden dengan responden yang bekerja.

Menurut Dinengsih (2018), pada ibu yang bekerja waktu yang dimilikinya menjadi terbagi untuk bekerja, sehingga perhatian tidak dapat diebrikan seutuhnya untuk anak. Pada ibu yang tidak bekerja akan lebih memiliki banyak waktu untuk ke poyandu atau ke pelayanan kesehatan. Kegiatan posyandu seringnya dilakanakan pada pagi hari, namun bagi ibu yan bekerja, pagi hari adalah waktu untuk bekerja, sehingga banyak ibu yang bekerja kesulitan untuk pergi ke posyandu. Sehingga bayi maupun balita akhirnya diberikan imunisasi bukan di posyandu mapun imunisasi diantar oleh pengasuh atau neneknya. [17]

Pelaksanaan penelitian juga dilakukan bersamaan dengan kegiatan Work From Home (WFH) yang disebabkan oleh karena pandemic COVID-19, akibatnya sehingga responden/ ibu yang bekerja atau hanya bekerja dirumah saja akan mempunyai lebih banyak waktu untuk anaknya namun tetap melaksanakan pekerjaannya. Sementara ibu yang tidak bekerja, ibu yang tidak bekerja lebih banyak memiliki waktu di rumah bersama anak dan cenderung lebih memperhatikan kesehatan anak, dalam hal ini adalah pemberian imunisasi anak.[18]

Berbeda dengan hasil penelitian Mandowa (2014), hasil uji ststistik dengan menggunakan metode fisher exact test, maka diperoleh nilai $\rho=0,025$. Dan nilai $\rho<\alpha$ $(0,05)$, maka dapat disimpulkan bahwa "Terdapat hubungan antara pekerjaan dengan kepatuhan ibu dalam pemberian imunisasi Dasar. Dengan status pekerjaan ibu dapat mempengaruhi status kesehatan anak termasuk 
melaksanakan imunisasi pada bayi maupun balitanya. Karena sebagian ibu yang bekerja banyak yang dapat dapat bertukar informasi dengan teman sekerja lebih terpapar dengan program-program kesehatan, khususnya imunisasi. Sehingga pekerjaan mempengaruhi kepatuhan ibu dalam pemberian imunisasi. [16]

\section{Kecemasan Ibu terhadap Pandemi dengan Kepatuhan Ibu dalam Imunisasi}

Hasil uji Chi Square didapat $p_{\text {value }}=$ $0,0001(<0,05)$ hal ini berarti ada hubungan antara kecemasan ibu dengan kepatuhan ibu dalam imunisasi POR $=5.000(2.133-11.720)$ yang artinya responden dengan perasaan cemas 5 kali berisiko kurang patuh dibandingkan dengan responden dengan perasaan kurang cemas.

Di masa pandemic covid-19 ini, tidak sedikit orang tua dan juga pengasuh di Indonesia yang enggan membawa anak mereka ke fasilitas kesehatan untuk mendapatkan imunisasi dikarenakan takut tertular oleh virus corona ataupun karena alasan lainnya. Hal ini terungkap didalam sebuah survei persepsi masyarakat; dimana lebih dari sepertiga pengasuh dan orang tua memilih untuk tidak mengimunisasikan anak (23\%) dan sebagian lain masih ragu-ragu (13\%). Pada saat yang sama, penundaan imunisasi juga dapat membuat jutaan anak di Indonesia berisiko terkena penyakit seperti difteri, campak, dan polio. [19]

Menurut Huddah (2017) terjadinya kecemasan di pengaruhi oleh pengetahuan, sementara itu yang mempengaruhi pengetahuan adalah pendidikan, media massa/informasi, sosial budaya dan ekonomi, lingkungan, pengalaman dan usia. Faktor kekurang tahuan menimbulkan kekhawatiran yang membuat ibu cemas untuk melakukan imunisasi pada bayi

\section{KESIMPULAN}

Simpulan penelitian ini menunjukkan adanya hubungan antara variable usia ibu ( $p_{\text {value }}=$ $0,019<0,05)$, pendidikan $\left(p_{\text {value }}=0,003<0,05\right)$ pekerjaan $\left(p_{\text {value }}=0,005<0,05\right)$, kecemasan ibu $\left(p_{\text {value }}=0,0001<0,05\right)$, dan pendapatan keluarga $\quad\left(p_{\text {value }}=0,007<0,05\right)$ terhadap dan balitanya. Maraknya informasi covid 19 yang meresahkan ibu membuat ibu takut untuk keluar rumah dan memberikan pelayanan imunisasi pada anaknya. Berdasarkan hasil penelitian Ayu (2017), yang berjudul 'Hubungan Antara Pengetahuan Tentang Imunisasi Polio Dengan Tingkat Kecemasan Pasca Imunisasi Polio Di Pustu Kali Balok Bandar Lampung Tahun 2017'. Hasil penelitian menunjukkan hubungan antara pengetahuan tentang imunisasi polio dengan tingkat kecemasan pasca imunisasi polio di Pustu Kali Balok Bandar lampung tahun 2017, P-value $0.000<\alpha(0.05)$, dengan nilai Odd Ratio 7.167. [13] [1]

\section{Pendapatan Keluarga dengan Kepatuhan Ibu dalam Imunisasi}

Hasil uji Chi Square didapat $p_{\text {value }}=$ $0,007 \quad(<0,05)$ hal ini berarti ada hubungan antara pendapatan keluarga dengan kepatuhan ibu dalam imunisasi dengan $\mathrm{POR}=3.987$ (1.506-10.557) yang artinya responden dengan pendapatan < Rp 3.000.000 3,9 kali berisiko tidak patuh dibandingkan dengan responden dengan pendapatan $\geq \operatorname{Rp} 3.000 .000$.

$$
\text { Penelitian Mulyanit }
$$

menggambarkan tidak ada pengaruh pendapatan perkapita sesuai UMR dengan kepatahun ibu dalam imunisasi. Ibu yang melakukan imunisai dasar lengkap sebanyak $78,0 \%$, dengan rata rata keluarga mempunyai pendapatan per kapitanya $\geq$ UMR seluruhnya memberikan imunisasi dasar secara lengkap kepada anaknya (100\%). Namun setelah dilakukan uji Fisher's Exact didapatkan hasil $p$ value $1,000>(0,05)$, sehingga dapat disimpulkan bahwa tidak terdapat hubungan yang erat antara faktor pendapatan dengan kelengkapan imunisasi pada anaknya di Desa Sumberejo Kecamatan Mranggen Demak. [20]

kepatuhan ibu terhadap imunisasi pada masa pandemic covid 19.

Terima kasih kami ucapkan kepada STIKes Payung Negeri Pekanbaru yang memfasilitasi terlaksananya penelitian ini, begitu juga wali/ ibu bayi yang menjadi responden yang bersedia meluangkan waktu untuk peneliti dan Klinik Cahaya Bunda yang bersedia menjadi tempat untuk meneliti. 


\section{DAFTAR PUSTAKA}

[1] M. H. Hudhah and A. C. Hidajah, "Perilaku Ibu Dalam Imunisasi Dasar Lengkap Di Puskesmas Gayam Kabupaten Sumenep," J. PROMKES, vol. 5, no. 2, p. 167, 2018, doi: 10.20473/jpk.v5.i2.2017.167-180.

[2] Kementrian Kesehatan Republik Indonesia, "Buletin Surveilans PD3I \& Imunisasi," pp. 11-11, 2020.

[3] D. R. Juwita, "Makna Posyandu Sebagai Sarana Pembelajaran Non Formal Di Masa Pandemic Covid 19," Meretas J. Ilmu Pendidik., vol. 7, no. 1, pp. 1-15, 2020.

[4] Kementrian Kesehatan Republik Indonesia, Tingkatan cakupan dan mutu imunisasi lengkap. 2019.

[5] Dinas Kesehatan Propinsi Riau, Profil Kesehatan Propinsi Riau Tahun 2018. 2019.

[6] Dinas Kesehatan Kota Pekanbaru, Profil Kesehatan Kota Pekanbaru. 2020.

[7] Kementrian Kesehatan Republik Indonesia, Buku Ajar Imuniasi. 2015.

[8] Adzaniyah, "Faktor yang mempengaruhi kelengkapan imunisasi dasar di kelurahan krembangan utara," J. Berk. Epidemiol., vol. 2, no. 1, pp. 59-70, 2014.

[9] Peraturan Menteri Kesehatan Republik Indonesia, Informasi tentang virus korona. Jakarta: Kemenkes RI, 2020.

[10] KPPPA, Profil Anak Indonesia Sehat. Jakarta: Kementerian Pemberdayaan Perempuan dan Perlindungan Anak (KPPPA), 2020.

[11] K. Kesehatan, Modul Bahan Ajar Cetak Kebidanan. Asuhan Kebidanan Neonatus, Bayi, Balita Dan Anak Pra Sekolah. Jakarta: Kemenkes RI, 2016.

[12] R. Marmi, Asuhan Neonatus, Bayi, Balita dan Anak Prasekolah. Yogyakarta: Pustaka Pelajar, 2018.

[13] S. A. Ayu, "Hubungan Antara Pengetahuan Tentang Imunisasi Polio Dengan Tingkat Kecemasan Pasca Imunisasi Polio Di Pustu Kali Balok Bandar Lampung Tahun 2017," J.
Kesehat. Holistik, vol. 11, no. 3, pp. 175-179, 2017.

[14] S. Notoadmodjo, . Kesehatan Masyarakat Ilmu Dan Seni. Jakarta: Rineka Cipta, 2008.

[15] M. Senewe, S. Rompas, and J. Lolong, "Analisis Faktor-Faktor Yang Berhubungan Dengan Kepatuhan Ibu Dalam Pemberian Imunisasi Dasar Di Puskesmas Tongkaina Kecamatan Bunaken Kota Madya Manado," J. Keperawatan UNSRAT, vol. 5, no. 1, p. 109743, 2017.

[16] R. Mandowa, J. Kasim, N. Hasanuddin Makassar, and S. Nani Hasanuddin Makassar, "Faktor-Faktor Yang Berhubungan Dengan Kepatuhan Ibu Dalam Pemberian Imunisasi Dasar Diwilayah Kerja Puskesmas Tamalanrea," J. Ilm. Kesehat. Diagnosis, vol. 5, no. 4, pp. 2302-1721, 2014, [Online]. Available: https://docplayer.info/49429360-Faktorfaktor-yang-berhubungan-dengankepatuhan-ibu-dalam-pemberianimunisasi-dasar-diwilayah-kerjapuskesmas-tamalanrea.html.

[17] S. Dinengsih and H. Hendriyani, "Hubungan Antara Pendidikan, Pengetahuan, Dukungan Keluarga Dan Peran Tenaga Kesehatan Dengan Kepatuhan Ibu Dalam Melakukan Imunisasi Dasar Pada Bayi Usia 0-12 Bulan Di Desa Aweh Kabupaten Lebak Provinsi Banten," J. Kesehat. Kusuma Husada, pp. 202-212, 2018, doi: 10.34035/jk.v9i2.281.

[18] Dwi Ghunayanti Novianda and Q. Mochammad Bagus, "Faktor yang Berhubungan dengan Perilaku Ibu dalam Pemenuhan Imunisasi Dasar," $J$. Heal. Sci. Prev., vol. 4, no. 2, pp. 125133, 2020, doi: 10.29080/jhsp.v4i2.402.

[19] UNICEF, “Unicef 2020.” 2020, [Online]. Available: https://data.unicef.org/topic/childhealth/immunization/.

[20] L. M. Mulyanti Mifbakhuddin; Azizah, Nur, "Faktor-Faktor Yang Berhubungan Dengan Kelengkapan Imunisasi Dasar 
Pada Bayi Usia 9 - 11 Bulan Di Desa

Sumberejo Kecamatan Mranggen

Demak," J. Kebidanan, no. Vol 3, No 1

(2014): JURNAL KEBIDANAN, pp. 1-

7, 2014, [Online]. Available:

https://jurnal.unimus.ac.id/index.php/jur _bid/article/view/1072/1121. 